\title{
Design, synthesis and biological evaluation of novel betulinic acid derivatives
}

\author{
Shengjie Yang ${ }^{1,2}$, Na Liang ${ }^{1,2}, H_{u} \mathrm{Li}^{1,2}$, Wei Xue ${ }^{1,2}$, Deyu Hu ${ }^{1,2}$, Linhong Jin ${ }^{1,2}$, Qi Zhao ${ }^{1,2}$ and Song Yang ${ }^{1,2^{*}}$
}

\begin{abstract}
Background: Tumor, is one of the major reason for human death, due to its widespread occurrence. Betulinic acid derivatives have attracted considerable attention as cancer chemopreventive agents and also as cancer therapeutics. Many of its derivatives inhibit the growth of human cancer cell lines by triggering apoptosis. With this background, we planned to synthesize a series of betulinic acid derivatives to assess their antiproliferation efficacy on human cancer cell lines.

Results: A series of novel betulinic acid derivatives were designed and synthesized as highlighted by the preliminary antitumor evaluation against MGC-803, PC3, A375, Bcap-37 and A431 human cancer cell lines in vitro. The pharmacological results showed that some of the compounds displayed moderate to high levels of antitumor activities with most of new exhibiting higher inhibitory activities compared to BA. The $\mathrm{IC}_{50}$ values of compound $3 \mathrm{c}$ on the five cancer cell lines were $2.3,4.6,3.3,3.6$, and $4.3 \mu \mathrm{M}$, respectively. Subsequent fluorescence staining and flow cytometry analysis (FCM) indicated that compound 3c could induce apoptosis in MGC-803 and PC3 cell lines, and the apoptosis ratios reached the peak (37.38\% and 33.74\%) after $36 \mathrm{~h}$ of treatment at $10 \mu \mathrm{M}$.
\end{abstract}

Conclusions: This study suggests that most of betulinic acid derivatives could inhibit the growth of human cancer cell lines. Furthermore, compound 3c could induce apoptosis of cancer cells.

\section{Background}

Malignant neoplasm is the major cause of human death worldwide, mainly due to its high occurrence. Thousands of people die of cancer every year, despite aggressive treatment regimens including surgery, chemotherapy, radiation therapy, and palliative care. The situation demands urgent need for new therapies of therapeutic combinations to improve the survival and quality of life of cancer patients.

Betulinic acid (BA, 33-3-hydroxy-lup-20(29)-en-28-oic acid 1 ) is a naturally occurring pentacyclic triterpenoid [1] which exhibits various biological activities, such as antiHIV, anti-inflammatory, antioxidant, antiretroviral and antibacterial properties [2-6], Mostly recently, it has been employed as a potential anticancer agent by inhibition of topoisomerase [7-11]. BA, which is present as one of the major effective components of many traditional Chinese

\footnotetext{
* Correspondence: jhzx.msm@gmail.com

'State Key Laboratory Breeding Base of Green Pesticide and Agricultural Bioengineering, Key Laboratory of Green Pesticide and Agricultural

Bioengineering, Ministry of Education, Guizhou University, Guiyang 550025, P.R. China

${ }^{2} \mathrm{Ctr}$ for R\&D of Fine Chemicals, Guizhou University, Huaxi St, Guiyang
} 550025, China medicines [12], is widely distributed in the plant kingdom throughout the world [13]. BA has also been reported to inhibit growth of cancer cells, without affecting normal cells $[14,15]$ and its lack of cytotoxic activity has been demonstrated in human astrocytes, human dermal fibroblasts, peripheral blood lymphoblasts and animal studies [16,17]. In 1995, BA was reported as a highly selective growth inhibitor [18] of human melanoma, neuroectodermal and malignant tumor cells and was reported to induce apoptosis in these cells [19]. At the same time, a large number of BA derivatives have been synthesized to improve anti-HIV activity [20,21], to reduce the organ toxic effect of antitumor drugs [22] and to be evaluated as new anticancer agents [23]. Researchers have demonstrated that the presence of a polar substituent at the C-3 position was essential for the pharmacological activities of pentacyclic triterpenes [24]. According to the structure-activity relationship, a hydrogen donor group at ether $\mathrm{C}-3$ or $\mathrm{C}-28$ position could improve cell proliferation inhibition significantly when an acetyl group was present at the C-3 position. Kvasnia et al found that the antitumor activities of BA derivatives where acyl groups were introduced at the $\mathrm{C}-3$ position as well as $\mathrm{C}-28$
(C) Chemistry Central

(c) 2012 Yang et al.; licensee Chemistry Central Ltd. This is an Open Access article distributed under the terms of the Creative Commons Attribution License (http://creativecommons.org/licenses/by/2.0), which permits unrestricted use, distribution, and reproduction in any medium, provided the original work is properly cited. 


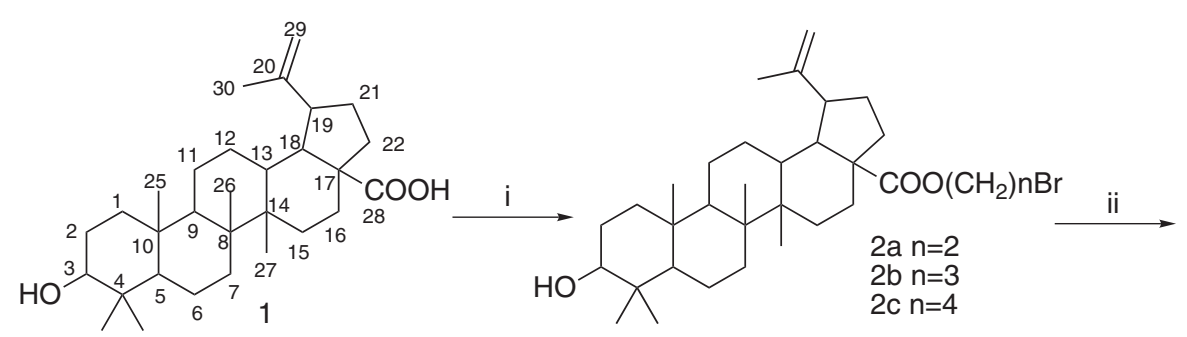

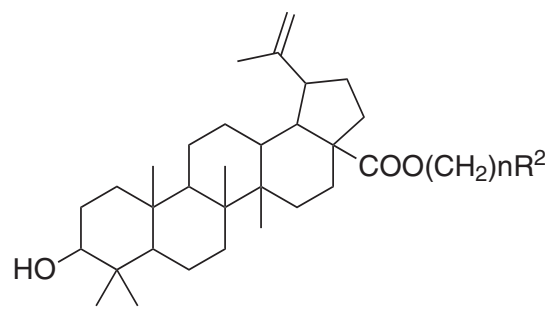

$$
\begin{array}{ll}
3 a n=2 R^{2}=-N & 3 g n=3 R^{2}=-N \\
3 b n=2 R^{2}=-N & 3 h n=3 R^{2}=-N
\end{array}
$$

Scheme 1 Synthetic route to BA derivatives. Reagents and conditions: (i) $\mathrm{BrCH}_{2} \mathrm{CH}_{2} \mathrm{Br}, \mathrm{BrCH}_{2} \mathrm{CH}_{2} \mathrm{CH}_{2} \mathrm{Br}$, or $\mathrm{BrCH} \mathrm{CH}_{2}\left(\mathrm{CH}_{2}\right)_{2} \mathrm{CH}_{2} \mathrm{Br}_{2} \mathrm{~K}_{2} \mathrm{CO}_{3}, \mathrm{DMF}$, r.t.; (ii) amine, $\mathrm{K}_{2} \mathrm{CO}_{3}$, DMF, r.t.

positions were improved significantly [25]. In recent years, the drug in which amino alkyl groups were introduced has attracted considerable attention. The studies have shown that incorporation of amino alkyl groups has led to unexpected improvements in the anti-HIV or antitumor activities of compounds [26].

In order to search for BA derivatives with high antitumor bioactivity, we performed herein synthesis of new pentacyclic triterpene derivatives, particularly those with substituents at the $28-\mathrm{COOH}$ position. The antiproliferative activities of the derivatives were evaluated against MGC-803, PC3, A375, Bcap-37 and A431 cell lines using MTT (thiazolyl blue tetrazolium bromide) assay in vitro. The results showed that some of the compounds displayed moderate to high levels of antitumor activities with most of new exhibiting more potent inhibitory activities compared to $\mathrm{BA}$. The $\mathrm{IC}_{50}$ values of compound $3 \mathrm{c}$ with the five cancer cell lines were 2.3, 4.6, 3.3, 3.6, and $4.3 \mu \mathrm{M}$, respectively. Furthermore, experimental results of fluorescent staining and flow cytometry analysis (FCM) indicated that compound $3 \mathrm{c}$ could induce apoptosis in MGC-803 and PC3 cell lines to the extent $37.38 \%$ and $33.74 \%$ respectively after $36 \mathrm{~h}$ of treatment at $10 \mu \mathrm{M}$. These apoptosis ratios were more compared with the positive controls HCPT (Hydroxycamptothecin).

\section{Results and discussion}

\section{Chemistry}

The synthesis of BA derivatives were summarized in Schemes 1-2. The structure modification on BA used as

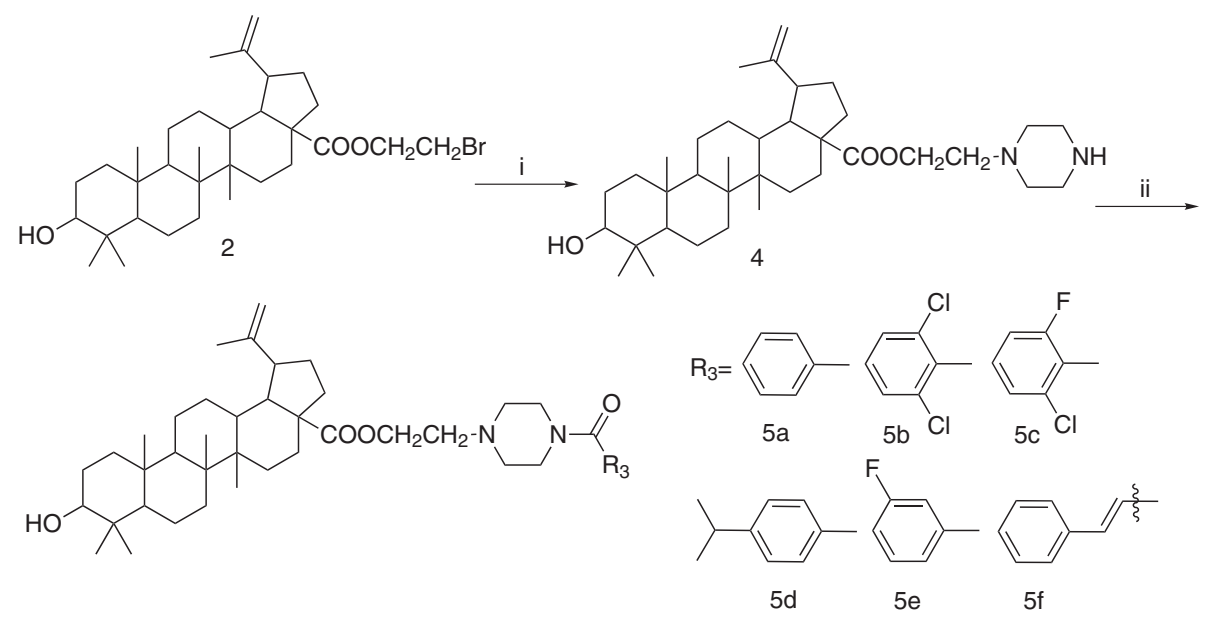

Scheme 2 Synthetic route to BA derivatives. Reagents and conditions: (i) piperazine, $\mathrm{K}_{2} \mathrm{CO}_{3}, \mathrm{DMF}, 80^{\circ} \mathrm{C}$; (ii) $\mathrm{EDCl}, \mathrm{HOBT}, \mathrm{R}^{3} \mathrm{COOH}, \mathrm{DCM}, \mathrm{r} . t$. 
the lead compound was done at the $\mathrm{C}-28$ position. BA was acetylated with 1,2-dibromoethane, 1,3-dibromopropane, or 1,4-dibromobutane in the presence of $\mathrm{K}_{2} \mathrm{CO}_{3}$ in $\mathrm{DMF}$ at room temperature to give the compounds $2 \mathrm{a}-2 \mathrm{c}$ with high yield. Then, the compounds $2 a-2 c$ were reacted with corresponding amines to give the nitrogencontaining derivatives $3 a-31$, respectively (Schemes 1 ). Compound 2a was treated with piperazine in DMF in the presence of $\mathrm{K}_{2} \mathrm{CO}_{3}$ at $80{ }^{\circ} \mathrm{C}$, and reacted with aromatic carboxylic acids to yield compounds $5 \mathrm{a}-5 \mathrm{f}$ (Schemes 2). All the compounds were fully characterized by their spectra data [see Additional file 1].

\section{Biological activity}

The in vitro antitumor activities were evaluated for the synthesized compounds against the MGC-803, PC3, A375, Bcap-37, and A431 cell lines. BA, ADM (Adriamycin), HCPT, and the compounds were dissolved in DMSO. ADM and HCPT were used as positive controls, and the negative control cells were treated with culture medium containing 0.1\% DMSO. When the $\mathrm{IC}_{50}$ (BA derivatives) could not reach the highest concentration, $>20 \mu \mathrm{M}$ was employed for our study. Each experiment was repeated at least three times. The results were summarized in Table 1.

As shown in Table 1, most of the modified compounds esterified at the 28- $\mathrm{COOH}$ with selected amino groups displayed significant further improvement of the cell growth inhibition. Compounds $3 \mathrm{a}-3 \mathrm{f}$ and $3 \mathrm{i}-3 \mathrm{j}$ presented strong inhibition against the above cancer cell lines. For example, the compound $3 \mathrm{c}$ showed considerable activity against the cancer cell lines (The $\mathrm{IC}_{50}$ values, 2.3, 4.6, 3.3, 3.6, and $4.3 \mu \mathrm{M}$, respectively). At the same time, it was found that active compounds showed antitumor activities against broader spectrum of tumors. Based on results we could summarize that the antiproliferative effect was significantly changed as the length of the carbon chain was increased $(2>3>4)$, such as compounds $3 \mathrm{a}, 3 \mathrm{e}$, and $3 \mathrm{i}$. However, when the $28-\mathrm{COOH}$ esterified with dibromoalkane, compounds $2 \mathrm{a}-2 \mathrm{c}$ had lower antitumor effects.

In addition, the compounds containing acyl piperazine moiety at $\mathrm{C}-28$ did not display higher inhibitory activity than the other, and some compounds only had moderate antitumor activities.

It has been reported that BA and its derivatives induce apoptosis and growth inhibition in certain cancer cell lines $[27,28]$. In the present study, compound 3c was selected to analyze the mechanism of growth inhibition of MGC-803 and PC3 cell lines by following assays.

The morphologic changes in the cell after treatment with compound $3 \mathrm{c}$ were assessed by fluorescene microscopy after staining with AO/EB. AO permeates all cells and makes the nuclei appear green. $E B$ is only taken up
Table 1 Inhibitory activity of BA and derivatives on different cancer cells proliferation

\begin{tabular}{|c|c|c|c|c|c|}
\hline \multirow[t]{2}{*}{ Compound } & \multicolumn{5}{|c|}{$\mathrm{IC}_{50}(\mu \mathrm{M}){ }^{\mathrm{a}}$ values against five human carcinoma cells } \\
\hline & MGC-803 ${ }^{b}$ & $\mathrm{PC}^{\mathrm{c}}$ & $A 375^{d}$ & Bcap-37 ${ }^{\mathrm{e}}$ & A431 ${ }^{f}$ \\
\hline 1 & $41.2 \pm 0.6$ & $67.2 \pm 0.5$ & $>100$ & $>100$ & $15.7 \pm 0.2$ \\
\hline $2 a$ & $>20$ & $>20$ & $>20$ & $>20$ & $>20$ \\
\hline $2 b$ & $>20$ & $>20$ & $>20$ & $>20$ & $>20$ \\
\hline $2 c$ & $>20$ & $>20$ & $>20$ & $>20$ & $>20$ \\
\hline $3 a$ & $3.5 \pm 0.5$ & $5.6 \pm 0.9$ & $3.4 \pm 0.1$ & $5.5 \pm 0.8$ & $4.8 \pm 0.2$ \\
\hline $3 b$ & $3.4 \pm 0.2$ & $4.2 \pm 0.2$ & $6.0 \pm 0.4$ & $7.6 \pm 0.5$ & $5.7 \pm 0.2$ \\
\hline $3 c$ & $2.3 \pm 0.2$ & $4.6 \pm 0.5$ & $3.3 \pm 0.4$ & $3.6 \pm 1.2$ & $4.3 \pm 0.3$ \\
\hline $3 d$ & $7.6 \pm 2.1$ & $8.6 \pm 0.2$ & $12.4 \pm 1.1$ & $10.5 \pm 0.5$ & $11.8 \pm 0.6$ \\
\hline $3 e$ & $4.0 \pm 0.9$ & $3.8 \pm 1.1$ & $4.4 \pm 0.5$ & $3.0 \pm 1.1$ & $5.6 \pm 0.1$ \\
\hline $3 f$ & $4.3 \pm 0.2$ & $2.8 \pm 0.4$ & $2.7 \pm 0.3$ & $5.2 \pm 0.1$ & $3.5 \pm 0.6$ \\
\hline $3 g$ & $15.7 \pm 0.5$ & $13.4 \pm 0.9$ & $11.3 \pm 0.6$ & $16.2 \pm 0.5$ & $13.3 \pm 0.4$ \\
\hline $3 \mathrm{~h}$ & $12.7 \pm 1.2$ & $15.0 \pm 0.5$ & $11.6 \pm 0.5$ & $12.5 \pm 0.5$ & $9.6 \pm 0.9$ \\
\hline $3 i$ & $5.6 \pm 0.4$ & $7.9 \pm 0.5$ & $7.7 \pm 0.3$ & $6.8 \pm 1.2$ & $5.7 \pm 0.2$ \\
\hline 3j & $7.6 \pm 0.6$ & $13.4 \pm 0.7$ & $12.8 \pm 0.4$ & $7.5 \pm 0.6$ & $10.5 \pm 1.5$ \\
\hline $3 k$ & $16.7 \pm 0.5$ & $17.1 \pm 0.2$ & $>20$ & $>20$ & $15.7 \pm 0.7$ \\
\hline 31 & $11.8 \pm 0.3$ & $12.7 \pm 1.5$ & $13.9 \pm 0.8$ & $9.43 \pm 0.8$ & $7.0 \pm 0.4$ \\
\hline $5 a$ & $8.8 \pm 0.8$ & $10.1 \pm 0.5$ & $12.5 \pm 0.6$ & $9.4 \pm 0.7$ & $6.3 \pm 0.8$ \\
\hline $5 b$ & $13.4 \pm 0.1$ & $14.5 \pm 0.4$ & $15.3 \pm 2.3$ & $16.7 \pm 0.8$ & $12.9 \pm 1.2$ \\
\hline $5 c$ & $17.3 \pm 0.4$ & $>20$ & $>20$ & $>20$ & $>20$ \\
\hline $5 d$ & $>20$ & $18.9 \pm 0.3$ & $>20$ & $>20$ & $16.3 \pm 0.1$ \\
\hline $5 e$ & $>20$ & $>20$ & $>20$ & $>20$ & $>20$ \\
\hline $5 f$ & $15.4 \pm 0.6$ & $>20$ & $>20$ & $>20$ & $>20$ \\
\hline HCPT & $29.1 \pm 2.6$ & $34.5 \pm 1.5$ & $27.8 \pm 1.2$ & $28.1 \pm 1.0$ & $23.4 \pm 0.7$ \\
\hline ADM & $0.7 \pm 0.2$ & $0.6 \pm 0.1$ & $1.0 \pm 0.6$ & $1.2 \pm 0.2$ & $1.1 \pm 0.1$ \\
\hline
\end{tabular}

a Agent concentration (micromolar) that inhibited cell growth by $50 \% 72 \mathrm{~h}$ after treatment; ${ }^{\mathrm{b}}$ Human gastric cancer; ${ }^{\mathrm{c}}$ Prostate cancer; ${ }^{\mathrm{d}}$ Malignant melanoma; ${ }^{\mathrm{e}}$ Breast cancer; ${ }^{\mathrm{f}}$ Epidermoid carcinoma.

by cells when cytoplasmic membrane integrity is lost, and stains the nucleus with red and also dominates over AO. Thus live cells have a normal green nucleus; early apoptotic cells have bright green nucleus with condensed or fragmented chromatin; late apoptotic cells display condensed and fragmented orange chromatin; cells that died from direct necrosis have a structurally normal orange nucleus [29]. With HCPT and BA used as positive control at $10 \mu \mathrm{M}$ for $48 \mathrm{~h}$, the compound $3 \mathrm{c}$ at $5 \mu \mathrm{M}$ on MGC-803 and PC3 cells from 12 to $48 \mathrm{~h}$ was detected via $\mathrm{AO} / \mathrm{EB}$ staining.

As can be seen in Figure 1, green yellow or orange dots were detected in the HCPT after $48 \mathrm{~h}$. Cells under BA treatment changed only minimally and pycnosis could only be seen after $48 \mathrm{~h}$. And the cells treated with compound 3c from 12 to $48 \mathrm{~h}$ and $\mathrm{BA}$ for $24 \mathrm{~h}$ had changed. Yellow and orange dots in MGC-803 and PC3 cells showed early and late apoptotic cells, and the 

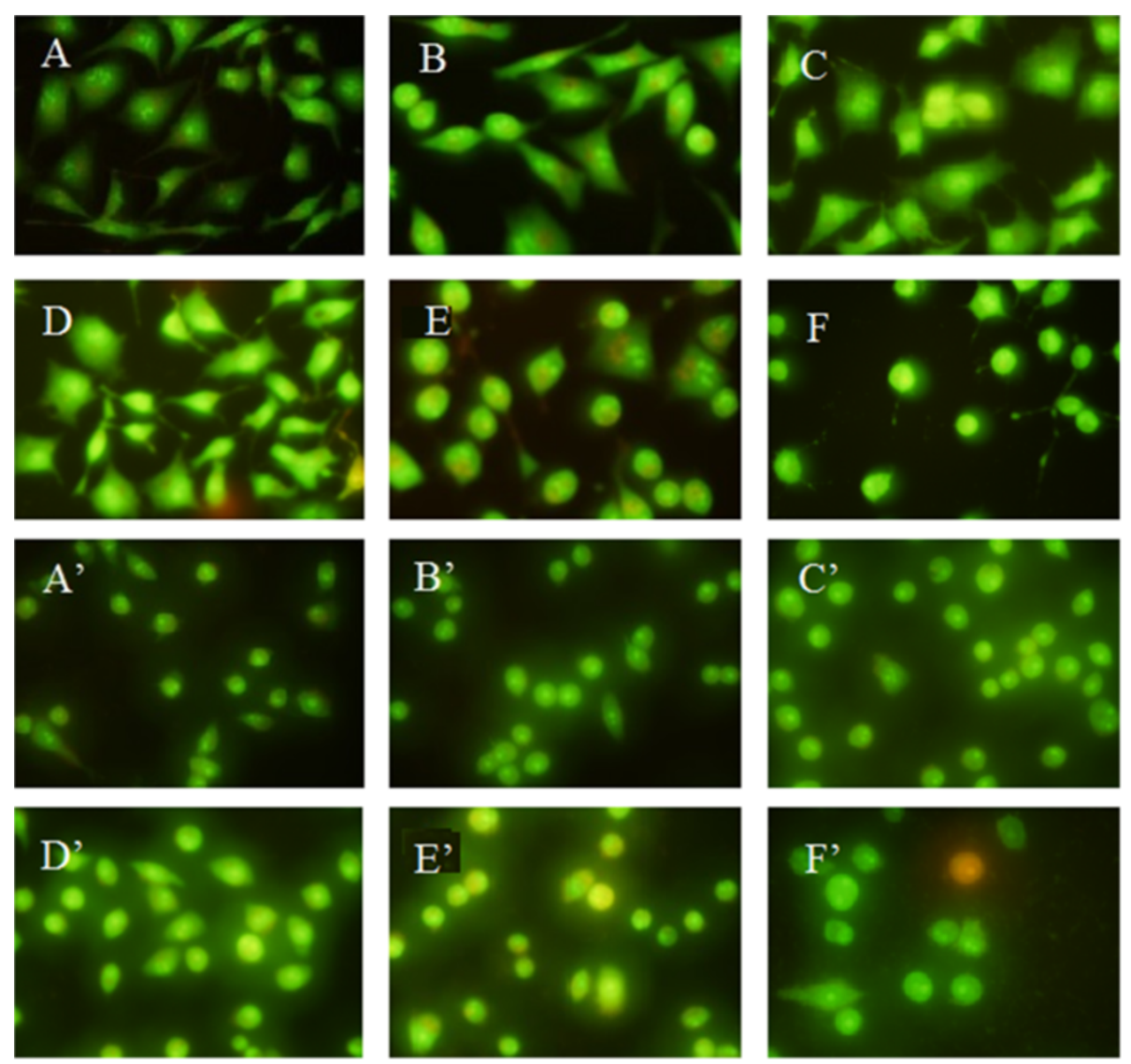

Figure 1 The AO/EB staining of compound $\mathbf{3 c}$ in tumor cells. For MGC-803 group, $\mathbf{A}$ : negative control; $\mathbf{B}$ and $\mathbf{C}$ : treated with HCPT and BA (10 $\mu \mathrm{M}$ each) as positive for $48 \mathrm{~h} ; \mathbf{D}, \mathbf{E}$, and $\mathbf{F}$ : treated with compound $3 c(5 \mu \mathrm{M})$ for $12 \mathrm{~h}, 24 \mathrm{~h}$, and $48 \mathrm{~h}$, respectively. For PC3 cells group, $\mathrm{A}^{\prime}$ : negative control; $\mathrm{B}^{\prime}$ and $\mathrm{C}^{\prime}$ : treated with HCPT and BA (10 $\mu \mathrm{M}$ each) as positive for $48 \mathrm{~h} ; \mathrm{D}^{\prime}, \mathrm{E}^{\prime}$, and $\mathrm{F}^{\prime}$ : treated with compound $3 \mathrm{C}(5 \mu \mathrm{M})$ for $12 \mathrm{~h}$, $24 \mathrm{~h}$, and $48 \mathrm{~h}$, respectively.

appearance of little red cells indicated that compound 3c was associated with low cytotoxicity. These findings show that compounds 3c could induce apoptosis with low cytotoxicity.

Hoechst 33258 is a hydrophilic and fluorescent probe only when bounded the DNA of cells, and live cells with uniformly light blue nuclei were treated with Hoechst 33258 [30]. The Hoechst 33258 staining showed apoptosis in all four types of cells, which were characterized by cytoplasmic and nuclear shrinkage, chromatin condensation and apoptosis body [31]. With HCPT and BA as positive control at $10 \mu \mathrm{M}$ for $48 \mathrm{~h}$, the compound $3 \mathrm{c}$ at $5 \mu \mathrm{M}$ on MGC-803 and PC3 cells from 12 to $48 \mathrm{~h}$ was detected via Hoechst 33258 staining.

As can be seen in Figure 2, the cells of the negative group (DMSO) were normal blue. However, the cells of HCPT group appeared compact condensed, and crescent-shaped. The cells exhibited strong blue fluorescence, revealing the typical apoptosis characteristics. The cells treated with compound $3 \mathrm{c}$ from 12 to $48 \mathrm{~h}$ and BA for $48 \mathrm{~h}$ had changed. The cell nuclei appeared to be highly condensed and crescent-shaped, indicating that compound 3c induced apoptosis against MGC-803 and PC3 cell lines. These results were identical with the previous $A O / E B$ double staining.

TUNEL is a common method for detecting DNA fragmentation that results from apoptotic signaling cascades. The assay relies on the presence of nicks in the DNA which can be identified by terminal deoxynucleotidyl transferase or $\mathrm{TdT}$, an enzyme that can catalyze the addition of dUTPs that are secondarily labeled with a marker. It may also label cells that have suffered severe DNA damage. Under a fluorescence microscope, the cells were observed with brown precipitate were the result of positive apoptosis. With HCPT and BA as positive control at $10 \mu \mathrm{M}$ for $48 \mathrm{~h}$, the compound $3 \mathrm{c}$ at $5 \mu \mathrm{M}$ against MGC-803 and PC3 cells from 12 to $48 \mathrm{~h}$ was detected via TUNEL assay.

As can be seen in Figure 3, the cells of the negative group (DMSO) did not appear as brown precipitates, whereas the other groups, namely, HCPT, appeared as brown precipitates. The cells treated with compound 3c 

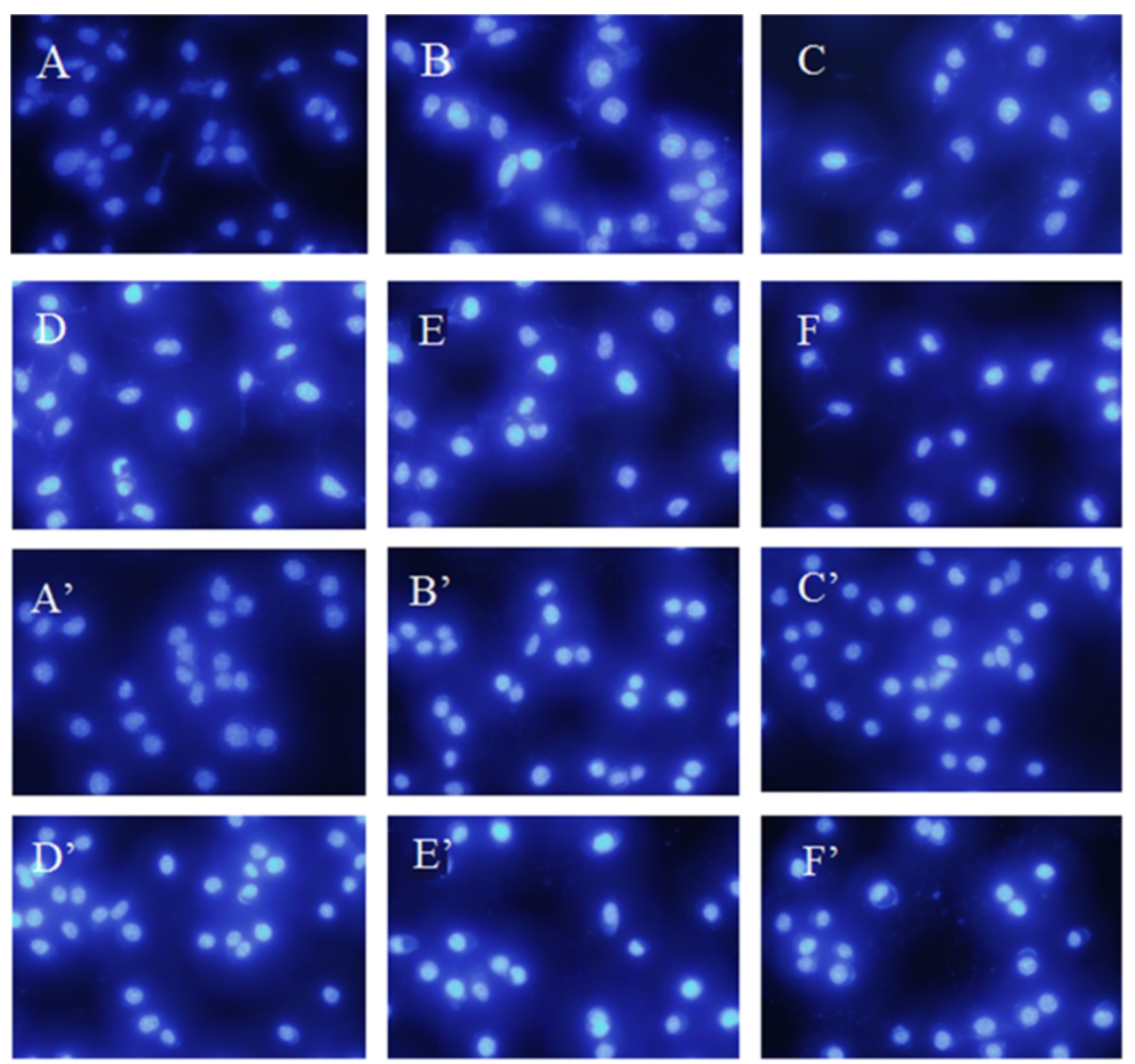

Figure 2 The Hoechst 33258 staining of compound $\mathbf{3 c}$ in tumor cells. For MGC-803 group, A: negative control; $\mathbf{B}$ and C: treated with HCPT and $\mathrm{BA}(10 \mu \mathrm{M}$ each) as positive for $48 \mathrm{~h} ; \mathbf{D}$, E, and $\mathbf{F}$ : treated with compound $3 c(5 \mu \mathrm{M})$ for $12 \mathrm{~h}, 24 \mathrm{~h}$, and $48 \mathrm{~h}$, respectively. For PC3 cells group, $A^{\prime}$ : negative control; $B^{\prime}$ and $C^{\prime}$ : treated with HCPT and BA (10 $\mu \mathrm{M}$ each) as positive for $48 \mathrm{~h} ; \mathrm{D}^{\prime}$, $\mathrm{E}^{\prime}$, and $\mathrm{F}^{\prime}$ : treated with compound $3 \mathrm{C}(5 \mu \mathrm{M})$ for $12 \mathrm{~h}, 24 \mathrm{~h}$, and $48 \mathrm{~h}$, respectively.

from 12 to $48 \mathrm{~h}$ and $\mathrm{BA}$ for $48 \mathrm{~h}$ had changed. Therefore, it can be further concluded that compound 3c induced apoptosis against MGC-803 and PC3 cells. The results were identical with the previous experiment.

The apoptosis ratios induced by compound 3c in tumor cells were quantitatively assessed by FCM. In early apoptotic cells, phosphatidylserine (PS) which distributed inside the lipid bilayer in the normal cells was transferred from the inside of the cell membrane to the outside. Annexin V was a calcium-dependent phospholipid binding protein that has a high affinity for the phophatidylserine PS, a plasma membrane phospholipid, used to detect early apoptotic cells. PI (Propidine Iodide) is an intercalating agent and a fluorescent molecule with a molecular mass of 668.4 Da that can be used to stain cells that had lost membrane integrity. So, the different periods of apoptotic cells could be distinguished when Annexin V matched with PI: necrotic cells (the upper left quadrant, Annexin $/ \mathrm{PI}^{+}$), late apoptotic cells (the upper right quadrant, Annexin ${ }^{+} / \mathrm{PI}^{+}$), intact cells (the lower left quadrant, Annexin ${ }^{-} / \mathrm{PI}^{-}$) and early apoptotic cells (the lower right quadrant, Annexin ${ }^{+} / \mathrm{PI}^{-}$) [32]. As shown in Figure 4, with HCPT as positive control, compound 3c $(10 \mu \mathrm{M})$ could induce apoptosis of MGC-803 and PC3 cells, and highest apoptosis ratios, $37.38 \%$ and $33.74 \%$ for compound 3c, were obtained after $36 \mathrm{~h}$ of treatment at a concentration of $10 \mu \mathrm{M}$. Furthermore, as shown in Figure 5 the apoptosis of MGC-803 and PC3 cells which were treated with compound $3 \mathrm{c}$ increased gradually in a time-dependent manner.

\section{Conclusions}

BA is an important natural product, and more and more studies have shown that BA has significant anticancer activity against various kinds of cell lines in vitro. In our study, a series of BA derivatives were designed, synthesized and evaluated their antitumor activities against the MGC-803, PC3, A375, Bcap-37, and A431 cell lines. Our data suggest that the C-28 amino substituted BA derivatives possess stronger antiproliferative ability. Eight compounds (3a-3f, 3i-3j) showed significant cell growth inhibition activity against the five cancer cell lines. The 

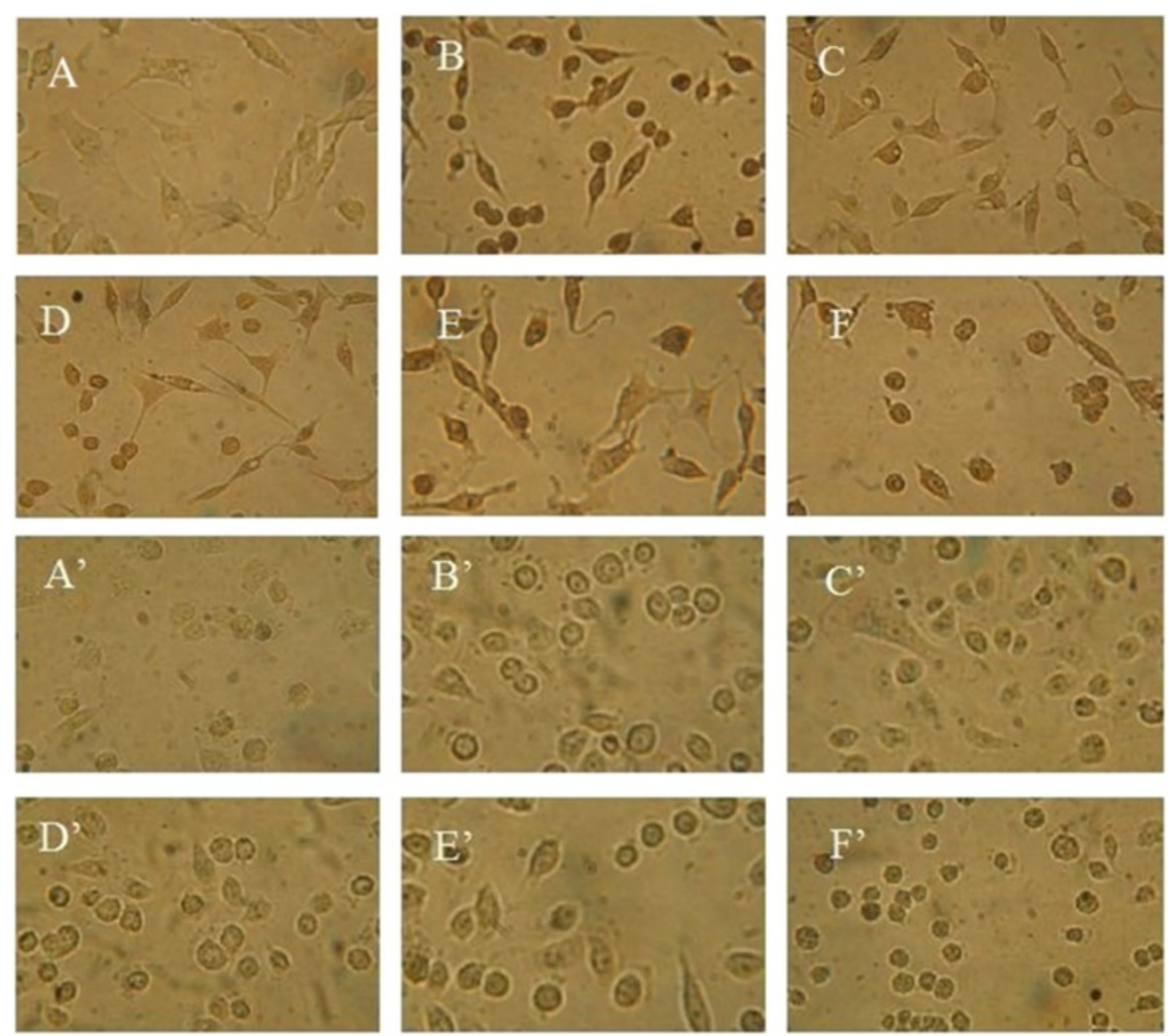

Figure 3 The TUNEL assay of compound $3 \mathbf{c}$ in tumor cells. For MGC-803 group, A: negative control; $\mathbf{B}$ and $\mathbf{C}$ : treated with HCPT and BA (10 $\mu \mathrm{M}$ each) as positive for $48 \mathrm{~h} ; \mathbf{D}, \mathbf{E}$, and $\mathbf{F}$ : treated with compound $3 c(5 \mu \mathrm{M})$ for $12 \mathrm{~h}, 24 \mathrm{~h}$, and $48 \mathrm{~h}$, respectively. For PC3 cells group, $\mathrm{A}^{\prime}$ : negative control; $B^{\prime}$ and $C^{\prime}$ : treated with HCPT and BA (10 $\mu \mathrm{M}$ each) as positive for $48 \mathrm{~h} ; \mathrm{D}^{\prime}, \mathrm{E}^{\prime}$, and $\mathrm{F}^{\prime}$ : treated with compound $3 \mathrm{c}(5 \mu \mathrm{M})$ for $12 \mathrm{~h}$, $24 \mathrm{~h}$, and $48 \mathrm{~h}$, respectively.

$\mathrm{IC}_{50}$ values of compound $3 \mathrm{c}$ against the five cancer cell lines were $2.3,4.6,3.3,3.6$, and $4.3 \mu \mathrm{M}$, respectively. However, the compounds containing an acyl piperazine moiety at C-28 did not display higher inhibitory activity, and some compounds only had moderate antitumor activity, but still more active than the parent BA.

In addition, the apoptosis-inducing activity of compound 3c in MGC-803 and PC3 cell lines was investigated by following assays: AO/EB staining, Hoechst 33258 staining, TUNEL assay and FCM. The preliminary mechanistic studies indicated that the compound 3c may inhibit cell growth by inducing apoptosis. The apoptosis ratio reached $37.38 \%$ and $33.74 \%$ after $36 \mathrm{~h}$ of treatment at $10 \mu \mathrm{M}$, higher than the ratios observed for the positive control HCPT (27.49\% and $23.53 \%$ respectively). These findings provide a very powerful incentive for further research on the chemical modification and structure-activity relationships of BA and other triterpenoid acids.

\section{Experimental}

\section{General procedures and reagents}

BA with more than $98 \%$ purity was purchased from Zhejiang Tiancao Biotech Co., Ltd. Reagents of analytical grade were obtained from Yuda Chemistry Co., Ltd., and used without further purification unless otherwise noted. Infrared spectra were recorded on a Bruker VECTOR22 spectrometer in $\mathrm{KBr}$ disks. ${ }^{1} \mathrm{H}$-NMR and ${ }^{13} \mathrm{C}$-NMR were recorded using a JEOL-ECX500 spectrometer at $22^{\circ} \mathrm{C}$, with tetramethylsilane as the internal standard and $\mathrm{CDCl}_{3}$ as the solvent. Column chromatography was performed using silica gel (200-300 meshes) (Qingdao Marine Chemistry Co., Qingdao, China)

\section{Cell lines and culture}

MGC-803, PC3, A375, Bcap-37 and A431 cell lines were obtained from the Institute of Biochemistry and Cell Biology, China Academy of Science. MGC-803 is gastric cancer cell line, PC3 is prostate cancer cell line, A375 is malignant melanoma cell line, Bcap-37 is breast cancer cell line, and A431 is epidermoid carcinoma cell line. The entire cancer cell lines were maintained in the RPMI 1640 medium. They were supplemented with 10\% heat-inactivated fetal bovine serum (FBS) in a humidified atmosphere of $5 \% \mathrm{CO}_{2}$ at $37^{\circ} \mathrm{C}$. All cell lines were maintained at $37^{\circ} \mathrm{C}$ in a humidified $5 \%$ carbon dioxide and 95\% air incubator. 


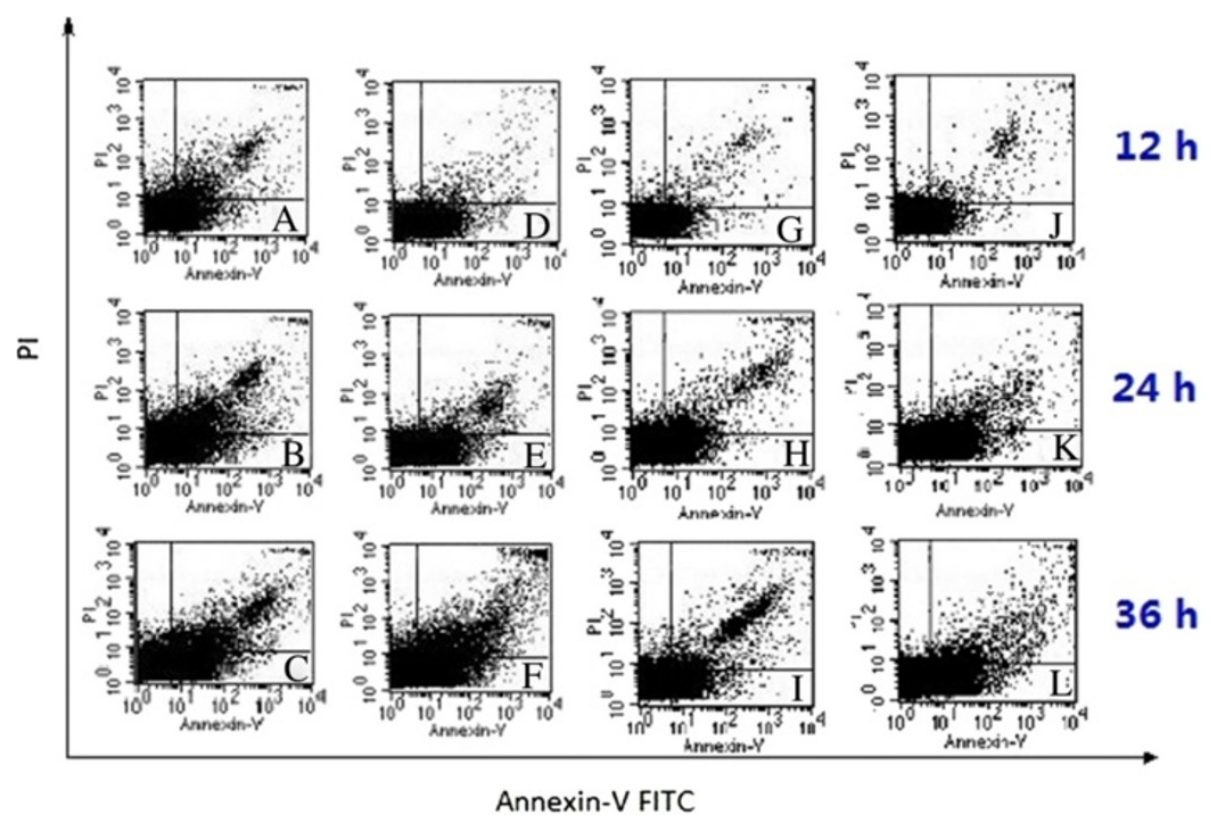

Figure 4 Annexin V/PI apoptosis ratio detection assay. The appearance of apoptosis cells was detected by flow cytometry using Annexin V/PI

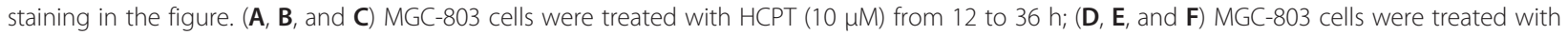
compound $3 c(10 \mu \mathrm{M})$ from 12 to $36 \mathrm{~h} ;(\mathbf{G}, \mathbf{H}$, and $\mathbf{I})$ PC3 cells were treated with HCPT (10 $\mu \mathrm{M})$ from 12 to $36 \mathrm{~h} ;(\mathbf{J}, \mathbf{K}$, and $\mathbf{L})$ PC3 cells were treated with compound $3 \mathrm{c}(10 \mu \mathrm{M})$ from 12 to $36 \mathrm{~h}$.

\section{MTT assays}

All tested compounds were dissolved in DMSO and subsequently diluted in the culture medium before treatment of the cultured cells. When the cells were $80-90 \%$ confluent, they were harvested by treatment with a solution containing $0.25 \%$ trypsin, thoroughly washed and resuspended in supplemented growth medium. Cells $\left(2 \times 10^{3} /\right.$ well $)$ were plated in $100 \mu \mathrm{L}$ of medium/well in 96-well plate. After incubations overnight, the cells were

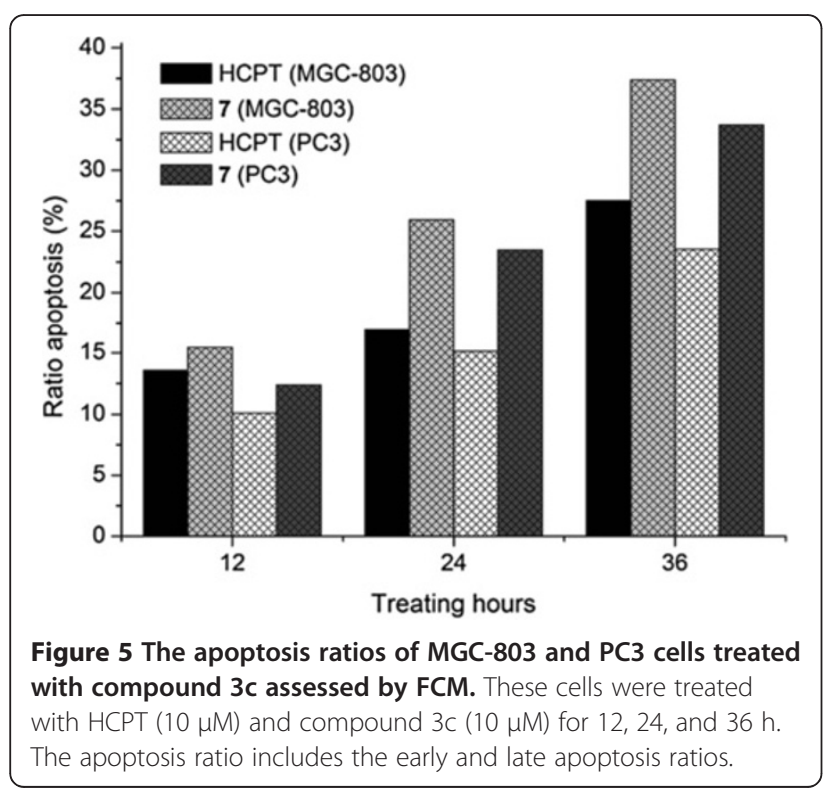

treated with different concentrations of extracts in RPMI 1640 with $10 \%$ FBS for $72 \mathrm{~h}$. In parallel, the cells treated with $0.1 \%$ DMSO served as negative control and ADM (Adriamycin) as positive control. Finally, $100 \mu \mathrm{L}$ of MTT was added, and the cells were incubated for $4 \mathrm{~h}$. The MTT-formazan formed by metabolically viable cells was dissolved in $100 \mu \mathrm{L}$ of SDS for $12 \mathrm{~h}$. The absorbance was then measured at $595 \mathrm{~nm}$ with a microplate reader, which is directly proportional to the number of living cells in culture.

\section{AO/EB staining}

When the cells were $80-90 \%$ confluent, they were harvested by treatment with a solution containing $0.25 \%$ trypsin, thoroughly washed and resuspended in supplemented growth medium. The cells were seeded at a concentration of $5 \times 10^{4}$ cell $/ \mathrm{mL}$ in a volume of $0.8 \mathrm{~mL}$ on a sterile cover slip in 6-well tissue culture plates. Following incubation, the medium was removed and replaced with fresh medium plus $10 \%$ FBS and then supplemented with compounds. After the treatment period, the cover slip with monolayer cells was inverted on the glass slide with $20 \mu \mathrm{L}$ of $\mathrm{AO} / \mathrm{EB}$ stain $(100 \mu \mathrm{g} / \mathrm{mL})$. The fluorescence was read using fluorescence microscope.

\section{Hoechst 33258 staining}

When the cells were $80-90 \%$ confluent, they were harvested by treatment with a solution containing $0.25 \%$ trypsin, thoroughly washed and resuspended in supplemented 
growth medium. The cells were seeded at a concentration of $5 \times 10^{4} \mathrm{cell} / \mathrm{mL}$ in a volume of $0.8 \mathrm{~mL}$ on a sterile cover slip in 6-well tissue culture plates, and were treated with compounds for a certain range of treatment time. The culture medium containing compounds was removed, and the cells were fixed in $4 \%$ paraformaldehyde for $10 \mathrm{~min}$. The cells were washed twice with PBS, and were consequently stained with $0.5 \mathrm{~mL}$ of Hoechst 33258 staining for $5 \mathrm{~min}$. The stained nuclei were washed twice with PBS, and were consequently observed under fluorescence microscope at $350 \mathrm{~nm}$ excitation and $460 \mathrm{~nm}$ emissions.

\section{TUNEL assay}

When the cells were $80-90 \%$ confluent, they were harvested by treatment with a solution containing $0.25 \%$ trypsin, thoroughly washed and resuspended in supplemented growth medium. The cells were seeded at a concentration of $5 \times 10^{4}$ cell $/ \mathrm{mL}$ in a volume of $0.8 \mathrm{~mL}$ on a sterile cover slip in 6-well tissue culture plates, and were treated with compounds for a certain range of treatment time. A) The MGC-803 and PC3 cells grown in 6-well tissue culture plates were washed with PBS and fixed in 4\% paraformaldehyde for $40 \mathrm{~min}$. B) The cells were washed once with PBS, and were then permeabilized with immunol staining wash buffer for $2 \mathrm{~min}$ on ice. The cells were rewashed once with PBS, and subsequently incubated in $0.3 \% \mathrm{H}_{2} \mathrm{O}_{2}$ in methanol at room temperature for $20 \mathrm{~min}$ to inactivate the endogenous peroxidases, after which the cells were washed thrice with PBS. C) Thereafter, the cells were incubated with $2 \mu \mathrm{L}$ of TdT-enzyme and $48 \mu \mathrm{L}$ of BiotindUTP per specimen for $60 \mathrm{~min}$ at $37^{\circ} \mathrm{C}$. The cells were terminated for $10 \mathrm{~min}$, and were subsequently incubated with streptavidin-HRP (50 $\mu \mathrm{L}$ per specimen) conjugate diluted at 1:50 in sample diluent for $30 \mathrm{~min}$. D) The cells were washed three times with PBS, and were then incubated with diaminobenzidine solution $(200 \mu \mathrm{L}$ per specimen) for $10 \mathrm{~min}$. E) The cells were rewashed twice with PBS, and were finally imaged under biological microscope.

\section{Flow cytometry analysis}

Prepared MGC-803 and PC3 cells $\left(1 \times 10^{6} / \mathrm{mL}\right)$ were washed twice with cold $\mathrm{PBS}$ and then re-suspended gently in $500 \mu \mathrm{L}$ binding buffer. Then the cells were stained in $5 \mu \mathrm{L}$ Annexin V-FITC and shaked well. $5 \mu \mathrm{L}$ PI was added to these cells and incubated for $20 \mathrm{~min}$ in a dark place, analyzed by FACS.

\section{Statistical analysis}

All statistical analyses were performed using SPSS 10.0, and the data were analyzed using one-way ANOVA. The mean separations were performed using the least significant difference method. Each experiment was performed in triplicate, and all experiments were run thrice and yielded similar results. Measurements from all the replicates were combined, and the treatment effects were analyzed.

\section{Additional file}

Additional file 1: Experimental details and data of BA derivatives.

Which includes the experimental procedure, spectroscopic data, and copies of ${ }^{1} \mathrm{H}$ NMR and ${ }^{13} \mathrm{C}$ NMR of selected compounds.

\section{Competing interests}

We have no competing interesting

\section{Author's contributions}

SY synthesized the compounds and carried out most of the bioassay experiments. NL and HL did part of the bioassay experiments. WX took part in the compound structural elucidation and bioassay experiments. DH and $\mathrm{LJ}$ carried out some structure elucidation experiments. QZ assisted in structural elucidation experiments. Prof. SY is the co-corresponding author for this work. All authors read and approved the final manuscript.

\section{Acknowledgments}

The authors wish to thank the National Key Program for Basic Research (Nos.2010CB126105, 2010CB134504), the National Natural Science Foundation of China (Nos. 21132003, 21172048), Guizhou Province S\&T Program (No. 20103052) for the financial support.

Received: 21 September 2012 Accepted: 12 November 2012 Published: 23 November 2012

\section{References}

1. de Melo CL, Queiroz MGR, Filho ACV, Rodrigues AM, Sousa DF, Almeida JG, Pessoa OD, Silveira ER, Menezes DB, Melo TS, Santos FA, Rao VS: Betulinic acid, a natural pentacyclic triterpenoid, prevents abdominal fat accumulation in mice fed a high-fat diet. J Agric Food Chem 2009, 57:8776-8781

2. Fujioka T, Kashiwada Y, Kilkuskie RE, Cosentino LM, Ballas LM, Jiang JB, Janzen WP, Chen IS, Lee KH: Anti-AIDS agents, 11. Betulinic acid and platanic acid as anti-HIV principles from Syzigium claviflorum, and the anti-HIV activity of structurally related triterpenoids. J Nat Prod 1994 57:243-247

3. Nguemfo EL, Dimo T, Dongmo AB, Azebaze AG, Alaoui K, Asongalem AE, Cherrah $Y$, Kamtchouing P: Anti-oxidative and anti-inflammatory activities of some isolated constituents from the stem bark of Allanblackia monticola Staner L.C (Guttiferae). Inflammopharmacolocgy 2009, 17:37-41.

4. Tzakos AG, Kontogianni VG, Tsoumani M, Kyriakou E, Hwa J, Rodrigues FA, Tselepis AD: Exploration of the antiplatelet activity profile of betulinic acid on human platelets. J Agric Food Chem 2012, 60:6977-6983.

5. Onwuchekwa C, Oluwole FS: Anti-gastric ulcer and anti-inflammatory properties of betulinic acid in male albino rats. Sci W J 2010, 5:15-17.

6. Yogeeswari $P$, Sriram D: Betulinic acid and its derivatives: A review on their biological properties. Curr Med Chem 2005, 12:657-666.

7. Chowdhury AR, Mandal S, Mittra B, Sharma S, Mukhopadhyay S, Majumder HK: Betulinic acid, a potent inhibitor of eukaryotic topoisomerase I: Identification of the inhibitory step, the major functional group responsible and development of more potent derivatives. Med SC Monitor 2002, 8:254-265.

8. Mukherjee R, Kumar V, Srivastava SK, Agarwal SK, Burman AC: Betulinic acid derivatives as anticancer agents: structure activity relationship. Anticancer Agents Med Chem 2006, 6:271-279.

9. Fulda S, Debatin KM: Sensitization for anticancer drug-induced apoptosis by betulinic acid. Neoplasia 2005, 7:162-170.

10. Mullauer FB, Kessler JH, Medema JP: Betulinic acid, a natural compound with potent anticancer effects. Anti-Cancer Drugs 2010, 21:215-227.

11. Fulda S: Betulinic acid: a natural product with anticancer activity. Mol Nutr Food Res 2009, 53:140-146.

12. Tan $Y, Y u$ R, Pezzuto JM: Betulinic acid-induced programmed cell death in human melanoma cells involves mitogen-activated protein kinase activation. Clin Cancer Res 2003, 9:2866-2875. 
13. Viji V, Helen A, Luxmi VR: Betulinic acid inhibits endotoxin-stimulated phosphorylation cascade and pro-inflammatory prostaglandin E2 production in human peripheral blood mononuclear cells. Br J Pharmacol 2011, 162:1291-1303.

14. Chintharlapalli S, Papineni S, Lei P, Pathi S, Safe S: Betulinic acid inhibits colon cancer cell and tumor growth and induces proteasomedependent and -independent downregulation of specificity proteins (Sp) transcription factors. BMC Cancer 2011, 11:371-383.

15. Fulda S: Betulinic acid for cancer treatment and prevention. Int J Mol Sci 2008, 9:1096-1107.

16. Faujan NH, Alitheen NB, Yeap SK, Ali AM, Muhajir AH, Ahmad FBH: Cytotoxic effect of betulinic acid and betulinic acid acetate isolated from Melaleuca cajuput on human myeloid leukemia (HL-60) cell line. A J Bio 2010, 9:6387-6396.

17. Mashitoh AR, Yeap SK, Ali AM, Faujan A, Suhaimi M, Ng MK, Lam HY, Alitheen NB: Immunomodulatory effects of betulinic acid isolation from the bark of Melaleuca cajuputi. Pertanika J Trop Agric Sci 2012, 35:293-305.

18. Cichewicz RH, Kouzi SA: Chemistry, biological activity, and chemotherapeutic potential of betulinic acid for the prevention and treatment of cancer and HIV infection. Med Res Rev 2004, 24:90-114.

19. Pisha E, Chai H, Lee IS, Chagwedera TE, Farnsworth NR, Cordell GA, Beecher $\mathrm{CW}$, Fong $\mathrm{HH}$, Kinghorn AD, Brown DM: Discovery of betulinic acid as a selective inhibitor of human melanoma that functions by induction of apoptosis. Nat Med 1995, 1:1046-1051.

20. Hashimoto F, Kashiwada Y, Cosentino LM, Chen CH, Garrett PE, Lee KH: Anti-AIDS agents-XXVII. Synthesis and anti-HIV activity of betulinic acid and dihydrobetulinic acid derivatives. Bioorg Med Chem 1997, 5:2133-2143.

21. Qian K, Kuo R, Chen C, Huang L, Natschke SLM, Lee K: Agents 81. Design, synthesis, and structure-activity relationship study of betulinic acid and moronic acid derivatives as potent HIV maturation inhibitors. J Med Chem 2010, 22:3133-3141.

22. Gauthier C, Legault J, Rondeau S, Pichette A: Synthesis of betulinic acid acyl glucuronide for application in anticancer prodrug monotherapy. Tetrahedron Lett 2009, 50:988-991.

23. Suresha C, Zhao H, Gumbsa A, Chettya CS, Bose HS: New ionic derivatives of betulinic acid as highly potent anti-cancer agents. Bioorg Med Chem Lett 2012, 22:1734-1738.

24. Rajendran $P$, Jaggi M, Singh MK, Mukherjee R, Burman AC: Pharmacological evaluation of $\mathrm{C}-3$ modified Betulinic acid derivatives with potent anticancer activity. Invest New Drugs 2008, 26:25-34.

25. Shao JW, Dai YC, Xue JP, Wang JC, Lin FP, Guo YH: In vitro and in vivo anticancer activity evaluation of ursolic acid derivatives. Eur J Med Chem 2011, 46:2652-2661

26. Gerrish D, Kim IC, Kumar DV, Austin H, Garrus JE, Baichwal V, Saunders M, McKinnon RS, Anderson MB, Carlson R, Plaza E, Yager KM: Triterpene based compounds with potent anti-maturation activity against HIV-1. Bioorg Med Chem Lett 2008, 18:6377-6380.

27. Eichenmüller $M$, Hemmerlein B, von Schweinitz D, Kappler R: Betulinic acid induces apoptosis and inhibits hedgehog signalling in rhabdomyosarcoma. Br J Cancer 2010, 29:43-51.

28. Mullauer FB, Kessler JH, Medema JP: Betulinic acid induces cytochrome c release and apoptosis in a Bax/Bak-independent, permeability transition pore dependent fashion. Apoptosis 2009, 14:191-202.

29. Ribble D, Goldstein N, Norris D, Shellman Y: A simple technique for quantifying apoptosis in 96-well plates. BMC Biotechnol 2005, 5:1-7.

30. Ghavami S, Tehrani FK, Hashemi M, Zarif MN: Possible involvement of a specific cell surface receptor for calprotectin-induced apoptosis in colon adenocarcinoma and carcinam cell lines (SW742 and HT29/219). J Sci I R Iran 2004, 15:3-11.

31. Liu MC, Yang SJ, Hu DY, Wu ZB, Yang S: Chemical constituents of the ethyl acetate extract of Belamcanda chinensis (L.) DC roots and their antitumor activities. Molecules 2012, 17:6156-6169.

32. Xu XQ, Gao XH, Jin LH, Bhadury PS, Yuan K, Hu DY, Song BA, Yang S: Antiproliferation and cell apoptosis inducing bioactivities of constituents from Dysosma versipellis in PC3 and Bcap-37 cell lines. Cell Div 2011, 6:1-14.

doi:10.1186/1752-153X-6-141

Cite this article as: Yang et al:: Design, synthesis and biological evaluation of novel betulinic acid derivatives. Chemistry Central Journal 2012 6:141.

Publish with ChemistryCentral and every
scientist can read your work free of charge
"Open access provides opportunities to our
colleagues in other parts of the globe, by allowing
anyone to view the content free of charge."
W. Jeffery Hurst, The Hershey Company.
- available free of charge to the entire scientific community
- peer reviewed and published immediately upon acceptance
- cited in PubMed and archived on PubMed Central
- yours - you keep the copyright
Submit your manuscript here:
http://www.chemistrycentral.com/manuscript/

